\title{
An Analysis of the Management Performance of Real Estate Development Company- Focusing on real estate development company in Seoul
}

\author{
Junsik Choi ${ }^{1}$, Gongcheol Jeong ${ }^{2}$, Jaehwan Kim $^{3}$ \\ ${ }^{1}$ Graduate Student, Major in Real Estate Studies, Faculty of Regional Development, \\ Kongju Nat'l University. Yesan, Chungnam, South Korea, Telephone: 82-41-330- \\ 1402 \\ ${ }^{2}$ Ph.D. Student, Major in Real Estate Studies, Faculty of Regional Development, \\ Kongju Nat'l University. Yesan, Chungnam, South Korea, Telephone: 82-41-330- \\ 1402 \\ $3 *$ Corresponding author, Associate Professor, Major in Real Estate Studies, Faculty \\ of Regional Development, Kongju Nat'l University. Yesan, Chungnam, South Korea, \\ Telephone: 82-41-330-1402 \\ ${ }^{1}$ sik7779@naver.com Kongju, ${ }^{2}$ schministop@hanmail.net, ${ }^{3}$ jaehwan@kongju.ac.kr
}

\begin{abstract}
This study focused on management performance analysis and productivity analysis on real estate development companies in Seoul among real estate development companies. Input variables were analyzed for efficiency and productivity through DEA through total asset, labor costs and non-current asset output variables through sales and net profit. By doing so, the government wanted to enhance the management efficiency of a real estate development company by analyzing its management performance.
\end{abstract}

Keywords: Real Estate Development Company, DEA, Productivity Index, Efficiency, Productivity ${ }^{l}$

\section{Introduction}

Real estate development refers to the act of creating land through construction work or transformation, building, water supply, remodeling, or repurposing of buildings[2]. Real estate development companies had existed in the past, but after the 1997 financial crisis, they began to appear rapidly in the 2000 s with a boom in the real estate market and implemented development projects, and as the 'Act on Management and Promotion of Real Estate Development' was enacted in 2007, they were allowed to carry out real estate development projects under the name of developers[11]." However, when the real estate market is fluctuating due to changes in real estate policies such as the June 19 real estate measures, the August 2 real estate measures and the September 13 real estate comprehensive measures[1], real estate development companies that use business processes based on short-term judgment, and business judgment that rely on timing or sensitization, are showing the need for a flexible management strategy away from the existing measures[3].

\footnotetext{
${ }^{1}$ Article history:

Received (March 17, 2019), Review Result (April 18, 2019), Accepted (May 19, 2019)
} 
Accordingly, it is intended to present the management strategy of the real estate development company by identifying the factors that cause the change in productivity through productivity analysis and how much change in the size of the change is made.

\section{Theoretical background}

\subsection{DEA}

DEA, which has been widely used since it was first published in 1978, is an analysis method that evaluates efficiency based on the results of input/output variables based on the Linear Planning Act[5]. An analysis of an entity's performance is also an important area in the use of DEA. A company's performance may easily gauge its short-term performance with profitability [4], but its long-term competitiveness is guaranteed when it achieves its growth and stability at the same time. In this regard, it is used in various ways in assessing and analyzing the management efficiency of manufacturers, financial companies and public institutions. As in this paper, based on variables extracted from the management evaluation index, it is used in many analyses as it can be utilized in the management performance analysis of enterprises.(Kim Min-seop 2011)

$$
\begin{aligned}
& \text { Equation. } 1 \\
& \operatorname{Max}_{u, v} \sum_{k=1}^{s} v_{k} y_{k p} \\
& \text { s.t } \sum_{j=1}^{m} u_{j} x_{j p}=1 \\
& \sum_{k=1}^{s} u_{k} y_{k i}-\sum_{j=1}^{m} u_{j} x_{j i} \leq 0, \forall i \\
& u_{j} \geq \varepsilon, v_{k} \geq e, \forall j, k
\end{aligned}
$$

where $y_{k i}$ refers to the amount of output element $k$ that the DMU generates, $x_{j i}$ to the amount of input $j$ used by DMU I, $v_{k}$ to the weight imposed on the output $\mathrm{k}, u_{j}$ to the weight imposed on the input component $j$, and $\varepsilon$ to the nonarchimedian infinity. In order to obtain a reference group, which is a collection of efficient DMUs, in the above expression, a double-parameter must be introduced and the margin variable $s^{-}, s^{+}$must be introduced. Here's what I'm going to do.

$$
\begin{gathered}
\text { Equation. } 2 \\
\min _{\theta, \pi} \theta-\varepsilon\left(s^{-}+s^{+}\right) \\
\text {s.t } \sum_{i=1}^{n} \pi_{i} x_{j i}-\theta x_{j p}+s_{j}^{-}=0, \forall j \\
\sum_{i=1}^{n} \pi_{i} y_{k i}-y_{k p}-s_{k}^{+}=0, \forall k \\
\pi_{i}, s_{j}^{-}, s_{k}^{+} \geq 0 \forall i, j, k
\end{gathered}
$$

\subsection{Pre-Study Review}


Since there was no prior study that analyzed only the management performance of the real estate development company, it was classified as DEA.

Prior studies related to efficiency and productivity evaluation using DEA are as follows. As of December 31, 2010[10], It was analyzed 57 local builders listed on the stock market and KOSDAQ market for evaluation of their management efficiency. Park Jae-yeon [7] conducted an analysis using the management performance evaluation of 19 public corporations over a three-year period. Kim Bo-ram (2014) conducted a comparative analysis of the financial structure after classifying venture companies and small businesses, and selected 118 companies for analysis. Shin Young-kyun [12] used a total of 13 bank data from seven commercial banks and six local banks from 2007 to 2013 and conducted an analysis using the Financial Information Statistics System of the Financial Supervisory Service. After reviewing the DEA's prior research[9][13] the total number of assets, employees and capital were selected as inputs, and the calculation variables were selected to utilize sales and operating profit[8].

Based on the thesis that conducted the preceding study, the government selected total assets, labor costs and non-current assets as input variables and selected to utilize sales and net profit for output variables, and the efficiency and productivity analysis of Seoul-based real estate development companies with capital of less than 1 billion won using the 2018 disclosure data of the Financial Supervisory Service's electronic disclosure system is conducted to enhance the management performance of real estate development companies[6].

\section{Research model and analysis}

\subsection{Research model}

In this paper, enterprises selected as targets for productivity analysis for management performance analysis were selected as samples through the following process.

(1) Sampling of real estate development companies registered in 5,908 real estate development business as of 2019

(2) Check 3,574 development companies with less than 1 billion capital

(3) Among them, 324 real estate development companies were selected for the Seoul area only.

(4) Final selection of 46 places that collected data on audit reports for 2018 through the electronic disclosure system of the Financial Supervisory Service

In order to analyze the performance of the real estate development company, total assets, labor cost, and non - current asset variables were used as input variables, and sales and net income were used as the calculation variables.

Table 1. Input - output variable

\begin{tabular}{c|c}
\hline Input variable & Output variable \\
\hline Total assets & Take \\
Labor costs & Net Income \\
Non-current assets & \\
\hline
\end{tabular}

\subsection{Analysis procedure}

The input variables and the output variables of the sample firms selected for productivity analysis are shown

Table 2. Input variables of target sample (Unit: KRW) 


\begin{tabular}{|c|c|c|c|c|c|}
\hline \multirow{2}{*}{$\begin{array}{c}\mathrm{DM} \\
\mathrm{U}\end{array}$} & \multicolumn{3}{|c|}{ Input variable } & \multicolumn{2}{|c|}{ Output variable } \\
\hline & Total assets & Labor costs & $\begin{array}{l}\text { Non-current } \\
\text { assets }\end{array}$ & Take & Net Income \\
\hline 1 & $8,439,684,631$ & $286,276,000$ & $4,159,439,703$ & $15,476,179,163$ & $458,223,809$ \\
\hline 2 & $32,535,828,815$ & $\begin{array}{c}1,565,452,54 \\
0\end{array}$ & $\begin{array}{c}13,746,249,70 \\
0\end{array}$ & $69,388,952,065$ & $98,960,000$ \\
\hline 3 & $25,557,453,407$ & $277,510,850$ & $20,432,058$ & $57,304,518,543$ & $\begin{array}{c}13,509,220,83 \\
3 \\
\end{array}$ \\
\hline 4 & $32,838,089,644$ & $\begin{array}{c}1,407,166,72 \\
0\end{array}$ & $\begin{array}{c}14,378,507,69 \\
3\end{array}$ & $24,424,801,488$ & $3,141,981,501$ \\
\hline 5 & $21,495,359,625$ & $844,577,125$ & $\begin{array}{c}18,432,830,40 \\
3 \\
\end{array}$ & $4,384,113,848$ & $\begin{array}{c}- \\
3,892,710,059\end{array}$ \\
\hline 6 & $78,854,670,834$ & $\begin{array}{c}1,604,600,06 \\
0\end{array}$ & $\begin{array}{c}57,927,101,66 \\
4\end{array}$ & $14,039,487,106$ & $841,329,848$ \\
\hline 7 & $10,523,412,641$ & $340,078,327$ & $2,466,969,724$ & $5,542,268,671$ & $\begin{array}{c}- \\
2,043,077,457\end{array}$ \\
\hline 8 & $59,529,1$ & $\begin{array}{c}3,770,620,02 \\
2 \\
\end{array}$ & $\begin{array}{c}33,875,137,50 \\
4\end{array}$ & 107 & $\begin{array}{c}- \\
1,328,821,668\end{array}$ \\
\hline 9 & $25,816,013,876$ & $\begin{array}{c}1,920,350,13 \\
7 \\
\end{array}$ & $\begin{array}{c}13,135,478,84 \\
1 \\
\end{array}$ & $13,559,758,417$ & $4,590,987,939$ \\
\hline 10 & $\begin{array}{c}109,073,253,39 \\
7\end{array}$ & $349,476,820$ & $950,492,136$ & $87,815,009,105$ & $\begin{array}{c}12,089,725,25 \\
7\end{array}$ \\
\hline 11 & $15,476,078,465$ & $618,324,025$ & $6,443,312,069$ & $3,784,690,000$ & $-975,082,315$ \\
\hline 12 & $49,020,752,996$ & $425,203,600$ & $6,936,056,731$ & $50,644,885,495$ & $3,810,523,337$ \\
\hline 13 & $18,585,026,161$ & $\begin{array}{c}1,419,836,11 \\
2 \\
\end{array}$ & $5,342,285,779$ & $25,017,657,449$ & $852,358,980$ \\
\hline 14 & $17,063,747,451$ & $\begin{array}{c}2,377,247,07 \\
5 \\
\end{array}$ & $\begin{array}{c}14,102,630,56 \\
6\end{array}$ & $14,474,222,597$ & $68,047,726$ \\
\hline 15 & $18,290,676,248$ & $865,620,000$ & $1,516,652,735$ & $8,445,160$ & $\begin{array}{c}- \\
1,068,267,851\end{array}$ \\
\hline 16 & $\begin{array}{c}161,982,416,11 \\
0\end{array}$ & $\begin{array}{c}1,465,500,46 \\
0\end{array}$ & $\begin{array}{c}102,683,341,4 \\
97\end{array}$ & $4,010,164,984$ & $7,646,830,021$ \\
\hline 17 & $19,563,140,823$ & $681,702,339$ & $164,111,650$ & $10,353,969,981$ & $1,245,547,947$ \\
\hline 18 & $51,230,309,859$ & $358,668,764$ & $\begin{array}{c}13,597,935,03 \\
1\end{array}$ & $352,828,369$ & $\begin{array}{c}- \\
11,549,146,60 \\
3 \\
\end{array}$ \\
\hline 19 & $\begin{array}{c}120,610,153,83 \\
1\end{array}$ & $191,095,709$ & $2,923,777,948$ & $23,686,858,096$ & $\begin{array}{c}- \\
8,516,903,467\end{array}$ \\
\hline 20 & $\begin{array}{c}149,595,411,79 \\
0\end{array}$ & $179,538,595$ & $\begin{array}{c}144,874,975,3 \\
24\end{array}$ & $1,144,387,480$ & $392,956,179$ \\
\hline 21 & $\begin{array}{c}185,540,179,26 \\
8 \\
\end{array}$ & $971,788,719$ & $\begin{array}{c}32,399,558,47 \\
8 \\
\end{array}$ & $\begin{array}{c}118,210,745,80 \\
2 \\
\end{array}$ & $9,762,619,550$ \\
\hline 22 & $34,401,433,422$ & $\begin{array}{c}1,478,663,70 \\
3 \\
\end{array}$ & $9,832,928,004$ & $53,689,370,178$ & $192,647,115$ \\
\hline 23 & $50,679,997,081$ & $431,070,430$ & $3,233,900,924$ & $59,362,602,727$ & $7,635,003,463$ \\
\hline 24 & $\begin{array}{c}2,195,969,110 \\
328\end{array}$ & $\begin{array}{c}5,891,511,28 \\
6 \\
\end{array}$ & $\begin{array}{c}506,692,355,6 \\
05 \\
\end{array}$ & $\begin{array}{c}1,381,959,092 \\
165 \\
\end{array}$ & $\begin{array}{c}266,035,936,6 \\
15 \\
\end{array}$ \\
\hline
\end{tabular}




\begin{tabular}{|c|c|c|c|c|c|}
\hline 25 & $59,137,941,461$ & $\begin{array}{c}1,760,636,03 \\
4\end{array}$ & $2,618,508,828$ & $85,283,246,229$ & $3,516,803,578$ \\
\hline 26 & $5,488,898,079$ & $138,000,000$ & $3,076,052,061$ & $132,000,000$ & $-536,123,497$ \\
\hline 27 & $21,922,074,460$ & $608,005,160$ & $274,381,343$ & $32,559,688,430$ & $1,280,603,615$ \\
\hline 28 & $26,365,664,484$ & $183,317,950$ & $211,120,744$ & $2,547,882,160$ & $\begin{array}{c}- \\
1,986,679,229\end{array}$ \\
\hline 29 & $47,756,735,908$ & $977,051,210$ & $\begin{array}{c}29,084,011,67 \\
7 \\
\end{array}$ & $6,315,258,858$ & $\begin{array}{c}- \\
2,021,216,768\end{array}$ \\
\hline 30 & $\begin{array}{c}146,412,746,57 \\
6\end{array}$ & $\begin{array}{c}1,182,916,31 \\
0\end{array}$ & $3,275,042,764$ & $35,313,296,276$ & $\begin{array}{c}- \\
10,878,306,24 \\
1\end{array}$ \\
\hline 31 & $49,397,131,905$ & $125,731,427$ & $\begin{array}{c}45,517,932,91 \\
7\end{array}$ & $6,874,582,961$ & $8,120,182,168$ \\
\hline 32 & $56,350,354,947$ & $\begin{array}{c}1,617,692,33 \\
2 \\
\end{array}$ & $8,810,442,709$ & $\begin{array}{c}148,549,978,93 \\
8 \\
\end{array}$ & $6,188,888,997$ \\
\hline 33 & $28,274,683,222$ & $\begin{array}{c}1,332,417,98 \\
2\end{array}$ & $\begin{array}{c}13,867,162,96 \\
0\end{array}$ & $24,528,821,577$ & $1,535,622,292$ \\
\hline 34 & $34,504,581,614$ & $\begin{array}{c}17,824,965,7 \\
70\end{array}$ & $\begin{array}{c}24,347,100,17 \\
0\end{array}$ & $29,072,198,805$ & $2,490,916,639$ \\
\hline 35 & $22,054,173,223$ & $\begin{array}{c}1,911,716,26 \\
0\end{array}$ & $8,269,310,605$ & $27,942,550,125$ & $4,144,523,340$ \\
\hline 36 & $16,551,665,519$ & $\begin{array}{c}1,132,811,17 \\
5\end{array}$ & $5,732,872,378$ & $9,792,727,046$ & $2,730,746,383$ \\
\hline 37 & $29,619,030,859$ & $437,438,934$ & $8,077,561,057$ & $26,403,662,517$ & $1,783,668,940$ \\
\hline 38 & $\begin{array}{c}173,636,377,44 \\
6\end{array}$ & $634,689,520$ & $730,656,559$ & $6,558,000,000$ & $\begin{array}{c}- \\
13,552,250,26 \\
8 \\
\end{array}$ \\
\hline 39 & $43,612,143,245$ & $352,107,534$ & $9,283,187,128$ & $16,964,112,643$ & $\begin{array}{c}- \\
5,605,901,155\end{array}$ \\
\hline 40 & $54,401,837,931$ & $872,083,515$ & $4,483,522,168$ & $16,968,507,859$ & $\begin{array}{c}- \\
3,070,731,576\end{array}$ \\
\hline 41 & $31,433,611,396$ & $532,281,080$ & $316,859,286$ & $63,034,683,846$ & $\begin{array}{c}10,000,826,92 \\
8 \\
\end{array}$ \\
\hline 42 & $18,205,433,964$ & $427,147,265$ & $333,648,412$ & $6,715,616,022$ & $134,871,527$ \\
\hline 43 & $42,032,541,583$ & $\begin{array}{c}2,487,643,17 \\
4\end{array}$ & $\begin{array}{c}21,649,932,32 \\
1\end{array}$ & $10,297,197,236$ & $486,214,842$ \\
\hline 44 & $\begin{array}{c}145,649,883,43 \\
3 \\
\end{array}$ & $\begin{array}{c}3,084,099,90 \\
0 \\
\end{array}$ & $3,474,305,204$ & $\begin{array}{c}255,426,431,45 \\
9 \\
\end{array}$ & $\begin{array}{c}17,044,608,89 \\
5 \\
\end{array}$ \\
\hline 45 & $7,917,635,322$ & $239,400,000$ & $47,930,000$ & $34,606,110,800$ & $8,629,634,183$ \\
\hline 46 & $26,816,464,657$ & $150,607,663$ & $\begin{array}{c}22,765,797,71 \\
0 \\
\end{array}$ & $973,551,117$ & $46,706,250$ \\
\hline
\end{tabular}

In the sample, DEA analysis program was used to analyze the efficiency and productivity of the real estate development company, and meaningful results were obtained.

\section{Conclusion}

This study analyzed the efficiency and productivity of 46 real estate development companies in Seoul using DEA analysis. The total assets, labor costs, and non - current assets were selected 
as input variables for a clear analysis of management performance. The variables used are sales and net income. Efficiency and productivity analysis were attempted, but they have limitations in that they do not take into account clearer criteria for sample collection. In order to maximize the management efficiency of the real estate development company through the analysis of the management performance, it is necessary to conduct further research to derive a more usable research result.

\section{References}

[1] K. Boram, Editor, A Study on Evaluation of the Effectiveness of the Innovative SMEs and the General SMEs Using a DEA Model, Hanyang University, Seoul (2014), pp:24-26.

[2] K. Hyungwon, Editor, A Study on the factors affecting the profitability of real estate developement corporations, Kangnam University, Gyeonggi-do (2010), pp:15-19.

[3] K. Jaehwan, Editor, Real Estate Development Theory: Understanding Business Feasibility Analysis, Bookk, Bucheon (2016), pp:112-120.

[4] K. Minsub, Editor, Builder Management Efficiency Evaluation Using DEA, Yeungnam University, Gyeongsan (2011), pp:31-34.

[5] L. DongKwan, Editor, A Study on the Developmental Plan and the Improvement of Real Estate Development Project Registration System, Dong-Eui University, Busan (2010), pp:24-26.

[6] L. Jonggyu, Editor, Real estate development, Buyonsa, Seoul (2018), pp:151-158.

[7] P. Jaeyeon, Editor, An Efficiency Analysis of Public Organizations Using Data Envelopment Analysis, Sungkyunkwan University, Seoul (2012), pp:23-24.

[8] R. Jaehyun, H. Uksun and K. Yongsu, construction engineering and management. A Study on the Risk Reduction of Real Estate Development Projects and Improvement Schemes of Main Participant's Role - A Case Study Focused on Housing Development Projects -. Korea Institute of Construction Engineering \& Management. (2005), Vol.6, No.3 pp.135-143.

[9] S. Jinsoo and L. Sangyoung, KOREA REAL ESTATE ACADEMY REVIEW. Change and Development Directions of Developer for Risk Reduction of Real Estate Development Business. Korea Real Estate Academy. (2011), Vol.44, pp.167-183.

[10] S. Youngbang, Editor, A Study on the Scheme to Improve the Real Estate Development Business System, Jeonju University, Jeonju (2011), pp:29-32.

[11] S. Younggyun, Editor, A Study on the Comparison Analysis of Efficiency of Domestic Bank Using DEA, Pusan National University, Busan (2014), pp:9-13.

[12] Y. Youngsik and S. Joohan, KOREA REAL ESTATE ACADEMY REVIEW. A Study on the Efficient Risk Management with the Relative Importance of Risk Facts by Stage in the Real Estate Development Project. Korea Real Estate Academy. (2014), Vol.59, pp.59-73.

[13] Y. Youngsik, Editor, Real Estate Development Theory and Practice, Education Science History, Paju (2016), pp:71-74.

\section{Authors}




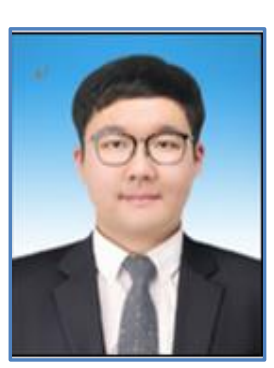

\section{Mr. Junsik, Choi}

$\mathrm{He}$ is a graduate student at the Department of Regional development, Kongju Nat'1 University, South Korea. His research interest are real estate development project, housing policy, and statistical methodology.

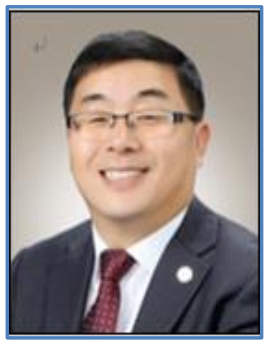

\section{Mr. Gongcheoul Jeong}

$\mathrm{He}$ is a Ph.D. student at the Department of Regional development, Kongju Nat'1 University, South Korea. His research interest are commercial and residential property development and real estate policy in local market.

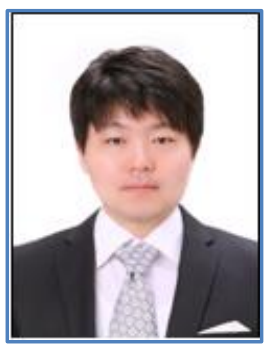

\section{Dr. Jaehwan, Kim}

$\mathrm{He}$ is a associate professor at the Department of Regional development, Kongju Nat'1 University, South Korea. His research interest are mixed use development, feasibility study, and decision making methodology. 
An Analysis of the Management Performance of Real Estate Development Company- Focusing on real estate development company in Seoul - 